\title{
Tumor necrosis factor-alpha polymorphism and susceptibility to juvenile idiopathic arthritis
}

\author{
S Bayraktar*, O Kasapcopur, N Arisoy, B Batar and M Guven
}

Address: Istanbul University, Cerrahpasa Medical School, Istanbul, Turkey

* Corresponding author

from $15^{\text {th }}$ Paediatric Rheumatology European Society (PreS) Congress

London, UK. 14-17 September 2008

Published: 15 September 2008

Pediatric Rheumatology 2008, 6(SuppI I):P6 doi:I0.I I86/I546-0096-6-SI-P6

This abstract is available from: http://www.ped-rheum.com/content/6/SI/P6

(c) 2008 Bayraktar et al; licensee BioMed Central Ltd.

\section{Background}

Juvenile idiopathic arthritis (JIA) is a complex, multifactorial and chronic inflammatory disease of unknown etiology with considerable variability in which tumor necrosis factor-alpha (TNF- $\alpha$ ) plays an important role. Both genetic and environmental factors can contribute to a susceptibility to disease initiation as well as a severity of disease course. TNF- $\alpha$ polymorphisms may be an independent marker of susceptibility and severity of JIA. The aim of this study was to elucidate putative association between the $-863 \mathrm{C} / \mathrm{A}$ polymorphism in the promoter region of the TNF-a gene and susceptibility to onset and severity of JIA.

\section{Methods}

We used PCR-RFLP (polymerase chain reaction - restriction fragment length polymorphism) method to detect the $-863 \mathrm{C} / \mathrm{A}$ polymorphism. We analyzed DNA samples from 76 patients with JIA and 80 healthy individuals.

\section{Results}

The distribution of TNF- $\alpha$ genotypes in cases differed significantly from that in the controls, comparing TNF- $\alpha$ A carriers (CA or AA genotypes) with noncarriers (CC genotype $(\mathrm{OR}=2.49 ; 95 \% \mathrm{CI}: 1.21-5.14 ; \mathrm{P}=0.01)$. However, TNF- $\alpha-863 \mathrm{C} / \mathrm{A}$ allele frequencies were not significantly different between cases and controls.

\section{Conclusion}

The TNF- $\alpha$ CC genotype was associated with increased risk factor for JIA in a sample of Turkish patients. 